\title{
THE USE OF AHP METHOD FOR SELECTION OF SUPPLIER
}

\author{
Roman Hruška, Petr Průša, Darko Babić \\ Dept of Transport Management, Marketing and Logistics, University of Pardubice, \\ Pardubice, Czech Republic
}

Submitted 28 February 2013; resubmitted 30 May 2013; accepted 23 August 2013

\begin{abstract}
To increase flexibility in today's global marketplace is needed to remain competitive and respond to rapidly changing markets. From that point of view, supplier selection represents one of the most important functions to be performed by the purchasing department. The supplier selection is a multi-criterion problem which includes both quantitative and qualitative criteria. In order to select the best suppliers, it is necessary to make a trade off between these criteria. The article deals with supplier selection using the Analytic Hierarchy Process (AHP). AHP provides a framework for making effective decisions in complex decision situations (e.g. vendor selection), helps to simplify and accelerate the natural process of decision making. AHP is a method of decomposition of complex unstructured situation into simpler components, thus creating a hierarchical system problem. The paper describes the general design of model supplier selection using the AHP with an application of the proposed model in a manufacturing company that selects a suitable supplier of three potential suppliers. The aim of this paper is to understand the strategic operating decision area of the supplier selection process and to aid decision makers with varying degrees of importance to reach consensus in rating alternative suppliers.
\end{abstract}

Keywords: supplier selection; AHP; strategic supplier; optimization method; Saaty's method.

Reference to this paper should be made as follows: Hruška, R.; Průša, P.; Babić, D. 2014. The use of AHP method for selection of supplier, Transport 29(2): 195-203. http://dx.doi.org/10.3846/16484142.2014.930928

\section{Introduction}

The search for new suppliers is a priority for the most companies in order to upgrade the variety of their products range. This is essentially due to two main reasons. At first, more generally products life circle is very short (2-4 years) and new models must often be developed by using completely renewed material or with new technologies. Second, more industries are historically, a labour intensive sector. These aspects are expressed through a complex pattern of demand for material and labour.

Another fact is that the purchasing function has gained great importance in the supply chain management due to the factors such as globalization, increased value added in supply, and accelerated technological change. Supplier selection and evaluation is the process of finding the suppliers being able to provide the buyer with the right quality products and/or services at the right price, at the right quantities and at the right time. Evaluation and selection of suppliers is a typical multiple criteria decision making problem involving multiple criteria that can be both qualitative and quantitative. A key and perhaps the most important process of the purchasing function is the efficient selection of suppliers, objective of the supplier selection process is to reduce risk and maximize the total value for the buyer and it involves considering a series of strategic variables.

The reduction of the manufacturing depth leads to an increase of the proportion of the purchased parts and consequently increases the dependency on suppliers (Maron, Brückner 1998). Kagnicioglu (2006) opines that supplier selection is a critical activity of purchasing management in a supply chain due to the key role of supplier's performance on cost, quality, delivery and service in achieving the objectives of a supply chain.

Selecting the right supplier may seem like an onerous process for supply chain. Simplistic supplier selection process may be helpful for some smaller supply chains, but more involved process of selecting the right suppliers is necessary for complex supply chains. Selection of right supplier can help companies to meet or exceed regulatory standards, drive customer demand and build a strong brand reputation of quality products.

Corresponding author: Petr Průša

E-mail: petr.prusa@upce.cz

Copyright $\odot 2014$ Vilnius Gediminas Technical University (VGTU) Press http://www.tandfonline.com/TRAN 
An efficient supplier management that begins with the identification of potential suppliers is of central importance for successful supply chain management (Lasch, Janker 2005). Also, proper supplier selection significantly reduces the purchasing costs and improves corporate competitiveness (Ghodsypour, O’Brien 2001). Lin (2009) opines that supplier selection for reducing supplier base is an important goal in Supply Chain Management (SCM).

The explicit consideration of multiple, conflicting objectives in a decision model has made the area of multi-ple criteria decision-making very challenging. Suppliers are considered as the best intangible assets of any organization. Suppliers have varied strengths and weaknesses that require careful assessment before placing the order. So, selection of suppliers is the most important decision making problem in today's competitive business environment.

Selecting the suppliers who can meet consumers' demand for higher-quality service or products may bring some initial costs, but it will pay off over time through consistent, high-grade materials. However, the process to find the ideal supplier is often not easy and requires expert and scientific approach.

This paper represents a summary (the results) of research which was carried out on a large number of logistics and production companies in order to consider the complexity and the problems of the supplier selection and the distribution network, their elements and action of the subsystem according to the defined criteria.

\section{Selection of a Supplier}

Purchasing department covers activity aimed at selecting the most suitable supplier and developing procedures and routines to select the best one. Van Weele (2010) defines purchasing as 'The management of the company's external resources in such a way that the supply of all goods, services, capabilities and knowledge which are necessary for running, maintaining and managing the company's primary and support activities is secured at the most favourable conditions'.

Cavinato et al. (2006), Pooler et al. (2004) are dealing with the role of purchasing. They declared that the role of purchasing has changed a great deal since the 1970s and they defined some more specific purchasing objectives:

- to get the best purchase - suitable quality at minimum cost;

- to pay reasonably low prices, negotiating and executing all company commitments;

- to develop satisfactory sources of supply and maintain good relationships with them;

- to secure optimal supplier performance, sometimes by seeking process improvements across boundaries between trading partners, etc.

The literature dealing with supplier selection/management is spread among the authors from the field of all industries, transportation and supply chain management. Some authors are dealing with choosing the ap- propriate performance metrics that aid in supplier selection and evaluation. Huang and Keskar (2007) say that cost and quality have been the most dominant factors along with on-time delivery and flexibility. Hsu et al. (2006) developed and validated a supplier selection construct and demonstrated that underlying the documented supplier selection criteria there is a need to assess a supplier's quality and service capabilities. Quality, delivery, price of materials and services, responsiveness and service consistently emerge to be the important criteria for supplier selection (Kannan, Tan, 2002; Verma, Pullman 1998).

Other approach deals with supplier rating/evaluation methods for a given set of performance metrics (Timmermann 1987; Weber et al. 1991). Lasch and Janker (2005) designed a supplier rating system that uses principal component analysis to create a classification and ranking of the potential suppliers by means of ellipsoid clusters. Huang and Keskar (2007) is a useful reference for literature review, for supplier selection using Analytical Hierarchy Process (AHP) and outranking methodologies as well as (Barbarosoglu, Yazgac 1997; Hill, Nydick 1992) which deals with supplier selection problems.

Also, suppler selection problem can be treated as a part of an optimization problem. To account for many conflicting and vague objectives and constraints in making supplier selection decisions, Kagnicioglu (2006) proposes a fuzzy multi-objective model, where both the objectives and some of the constraints are fuzzy. Morlacchi (1999) developed a model that combines the use of fuzzy set theory with AHP and implements it to evaluate small suppliers in engineering and machine sectors. Kumar et al. (2004) used fuzzy goal programming to deal with the effect of information uncertainty in supplier section problems. Ghodsypour and O'Brien (1997) used an integrated AHP model with mixed integer programming to reduce the number of suppliers.

As mentioned above the literature dealing with supplier selection/management is spread among the authors from the field of all industries and some of them are made models of AHP to support for the best-value contractor selection-lessons learned from two case studies in Taiwan (Wang et al. 2013), Podvezko et al. (2010) dealing with complex evaluation of contracts for construction, Bitarafan et al. (2012) in function of selecting the best supplier to evaluate the construction methods of cold-formed steel structures in reconstructing the areas damaged in natural crises, using the AHP and COPRASG, Hashemkhani Zolfani et al. (2012) made a hybrid MCDM model encompassing AHP and COPRAS-G methods for selecting company supplier in case study of Iran, Maskeliūnaitè and Sivilevičius (2012) carry out expert evaluation of criteria describing the quality of travelling by international passenger train, from technological, economic and safety perspectives.

In their own decisions about suppliers, company managers can proceed (according to available information and the severity of procurement decision) so that decision will be the result of these next mentioned methods (Lukoszová 2004). 
The common method is an expert estimate (team or individual). This method is based on the experience of responsible staff. Next method is a scoring model (relatively simple, but effective). The scoring model is quantitative evaluation of individual suppliers according to predetermined criteria. Another way of selecting a supplier is to compare their offers (e.g. in terms of pricelevel supplier). Combination of these methods is usually used in practice.

In literature (Lukoszová 2004; Tomek, Hofman 1999), there are some specific approaches to supplier selection, like following:

- a purchaser has the command to buy as cheaply as possible (it means that price as a factor has the highest importance;

- purchaser has an subjective approach to the imperfect ineffective his stimulation (e.g. for example, purchaser has not got any perspectives at the company, he/she is not stimulated to make an effort to ensure the most advantageous purchase);

- purchaser negotiates subjectively (puts greater emphasis on personal benefit than to benefit the company);

- selection of a form of 'competitive tendering' in exactly the legislatively defined procedures (e.g. for large government contracts).

In process of supplier selection, benchmarking can be used very often. Creating benchmarking test enables gathering objective information on the base of quantified indicators. Benchmarking enables to the company (manufacturer, logistic centre) to gather any time information necessary for decision making about increasing performance, productivity, total economic prosperity etc. (Kampf, Roudná 2009).

The article deals with the objective supplier selection, which can be achieved by using multi-criteria analysis (e.g. AHP). AHP provides a framework for making effective decisions in complex decision situations (e.g. vendor selection), helps to simplify and accelerate the natural process of decision making.

\section{Proposed Model of Supplier Selection Using AHP Method}

For selecting suitable supplier for the company (customer), AHP method can be used, like mentioned above. The AHP is systematic approach for selecting suppliers. People deal with complex decisions rather than prescribing a 'correct decision', the AHP helps people to determine one. Based on mathematics and human psychology, it was developed by Saaty (1980) and has been extensively studied and refined since then. AHP is a decision making method for prioritizing alternatives when multiple criteria must be considered and allows the decision maker to structure complex problems in the form of a hierarchy, or a set of integrated levels. Generally, the hierarchy has at least three levels: the goal, the criteria, and the alternatives. For the supplier selection problem, the goal is to select the best overall supplier. The criteria can be quality, price, service, delivery, etc.
The alternatives are the different proposals supplied by the suppliers.

This method provides the framework for effective decisions in complicated situations (e.g. supplier selection), helps to simplify and accelerate the natural process of decision making (Fig. 1).

The AHP is due to Saaty (1980) and is often referred to, eponymously, as the Saaty method, so in this paper we will refer on this method as mentioned.

Saaty's method is used at every level of hierarchical structure. Using the Saaty's method is assigned to each component of the quantitative characteristics reflecting their importance. The component with the highest priority is obtained by synthesis of these evaluations. The decision maker focuses on them to obtain a solution of the decision problem.

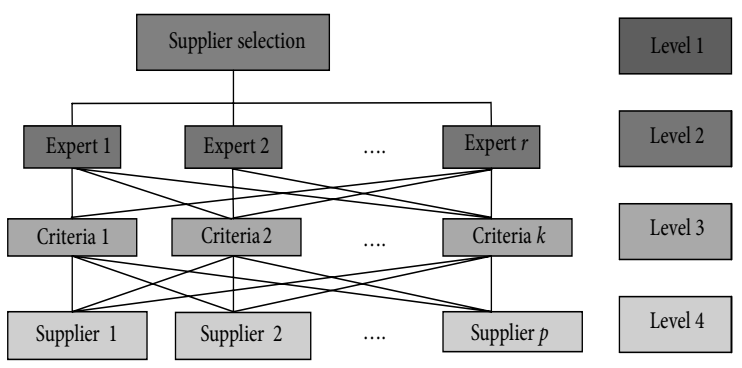

Fig. 1. Hierarchic system of problem - supplier selection: $r$ - total number of experts; $k$ - total number of criteria; $p$ - total number of suppliers

When solving the decision-making problem, it includes more experts. It has between the objective and criteria yet the level of evaluators (experts), theirs evaluations (weights) indicate the degree of their soundness.

The responsible supervisor can determine soundness of each expert who knows his subordinates (e.g. their job expertise, work experiences and results).

The soundness of experts can be written as a weight vector:

$$
v^{\text {experts }}=\left(v_{1}, v_{2}, \ldots ., v_{r}\right),
$$

where: $v_{1}$ - weight of 1 st expert; $v_{r}$ - weight of $r$ th expert;

$$
\sum_{j=1}^{r} v_{j}=1 .
$$

\section{Saaty's Method}

For the determination weights of criteria, Saaty's method has been chosen. This method takes into account the different preferences between the criteria and a wide point scale is determined for evaluation (Formula 3). It is therefore possible to detect even slight differences in preferences between the criteria, which are into account then in the process of setting the weights:

$$
\left(s_{i j}\right)=\left\{\begin{array}{l}
1-i \text { and } j \text { are equivalent; } \\
3-i \text { is mildly preferred to } j ; \\
5-i \text { is strongly preferred to } j ; \\
7-i \text { is very strongly preferred to } j ; \\
9-i \text { is absolutely preferred to } j .
\end{array}\right.
$$


Values 2, 4, 6, 8 are intended to evaluate intermediate stages. This method compares each pair of criteria $i$ and $j$. Their evaluation is written to the Saaty's matrix (Formula 4) according to the following rules:

$$
S=\left(\begin{array}{cccc}
1 & s_{12} & \ldots & s_{1 k} \\
1 / s_{12} & 1 & \ldots & s_{2 k} \\
\ldots & \ldots & \ldots & \ldots \\
1 / s_{1 k} & 1 / s_{2 k} & \ldots & 1
\end{array}\right) .
$$

This method involves 5 steps (Saaty 1980), which includes calculation of the weights $v_{i}$ using normalized geometric average of lines in Saaty matrix:

1. First, Saaty's matrix was filled so that the diagonal values are equal to one $\left(s_{i j}=1\right)$, If the $i$ th criterion is preferred to $j$ th criterion, then the appropriate value of Saaty's point scale (Formula 3), has to be selected. If the $j$ th criterion is preferred to $i$ th criterion, inverse values has to be written:

$s_{j i}=1 / s_{i j}$;

2. For every $i$, the value $s_{i}=\prod_{j=1}^{k} s_{i j}$ was calculated;

3. For every $i$, the value $R_{i}=\sqrt[k]{s_{i}}$ was calculated;

where: $R$ - geometric average; $k$ - total number of

4. In the next step, the value $\sum_{i=1}^{k} R_{i}$ was calculated;

5. In the last step of the method is determined weights of criteria according to the following formula:

$v_{i}=\frac{R_{i}}{\sum_{i=1}^{k} R_{i}}$.

Weights of criteria are determined if we multiply all elements for each row and determine the $n$th root of this product, when $n$ is the number of elements. Then we standardize resulting geometric averages of each Saaty's matrix row (we divide geometric averages of each row by the sum of all geometric averages).

This procedure gives estimate weights of each criterion, which can be written in the form of weight vector:

$$
v=\left(v_{1}, v_{2}, \ldots, v_{k}\right) \text {. }
$$

Saaty's method can be used not only to determine preferences between criteria, but also between variants, using the AHP.

\section{Defining Criteria for Supplier Selection}

Starting from the actual situation of the optimizing supplier selection there is a need for research and definition of criteria to set the models of their optimal choice. The selection of the criteria for the optimal supplier selection was based on the complexity of the system of the logistics and production companies i.e. on the fact that it is necessary to encompass as many infrastructural, functional, technical, technological and organisational data and services as possible, so that the proposed model can define optimal supplier with relevant characteristics.

So therefore, the first step in any supplier rating procedure is to find the appropriate criteria to be used for assessing the supplier. To comply with the criteria for supplier selection and their importance, required data were collected based on the consideration of literature.

In (Weber et al. 1991), the authors present a classification of all the articles published since 1966 according to the treated criteria. Based on 74 papers, they observe that 'Price', 'Quality', 'Payment terms' and 'Delivery time' are most often mentioned criteria in the literature.

Almost the same research work was performed by Zhang et al. (2004). In his work, researchers collected 49 articles from 1992 to 2003 and made a review according to mentioned method (Weber et al. 1991).

These researches have shown that supplier selection criteria are changing over the time period and these changes are affected by political, economic, social and environmental characteristics of business.

In this paper the authors selected the ten important criteria from the expletory literature review and discussion with experts.

The selected criteria are the most used criteria in many different industries. The selected criteria were found to cover most of the company's needs. In addition, the presence of too many criteria makes the pair-wise comparisons a difficult and time consuming process in evaluating suppliers. To overcome these problems, the cut-off value to reduce the number of criteria to a few is desirable. Ten important criteria which were selected by authors are:

- price $K_{1}^{V D}$;

- quality $K_{2}^{V D}$;

- payment terms $K_{3}^{V D}$;

- delivery time $K_{4}^{V D}$;

- willingness of hold stocks by supplier $K_{5}^{V D}$;

- financial situation of supplier $K_{6}^{V D}$;

- prospect of supplier development $K_{7}^{V D}$;

- service $K_{8}^{V D}$

- transport $K_{9}^{V D}$;

- audit of supplier $K_{10}^{V D}$,

where: $D$ - supplier; $K$ - criterion

The study was conducted in the Czech Republic, in the Czech language so VD stands for 'selection of supplier' (in the Czech language is 'výberr dodavatele').

Based on the consideration of literature, the priority weight of each criterion in each level was determined. For the determination of weights the Delphi method was used, as one of the types of expert methods which ensure the accuracy of the selection criteria.

After that the weights of criteria was calculated by Saaty's method. Table 1 shows the matrix of weights assigned to each criterion by $r$ th experts (Hruška 2011).

The aggregate weight for each criterion was calculated using the following formula:

$$
w K_{i}^{V D}=\sum_{j=1}^{r} v_{j} \cdot w_{i j},
$$

where: $w K_{i}^{V D}$ - aggregated weight of the $i$ th criterion 
Table 1. Matrix of weights assigned to each criterion by $r$ th experts

\begin{tabular}{l|l|l|l|l|l}
\hline Criterion & Expert $_{1}$ & Expert $_{2}$ & $\ldots$ & Expert $_{r-1}$ & Expert $_{r}$ \\
\hline$K_{1}^{V D}$ & & & & & \\
\hline$K_{2}^{V D}$ & & & & & \\
\hline$\ldots$ & & & & & \\
\hline$K_{k-1}^{V D}$ & & & & & \\
\hline$K_{k}^{V D}$ & & & & & \\
\hline
\end{tabular}

for selection of supplier, $i=1,2, \ldots, k ; v_{j}$ - weight $j$ th expert, $j=1,2, \ldots, r ; w_{i j}$ - weight of the $i$ th criterion assigned by $j$ th expert.

Aggregated weights of individual criteria for supplier selection can be written in the form of aggregated weight vector:

$$
w K^{V D}=\left(w K_{1}^{V D}, w K_{2}^{V D}, \ldots, w K_{k}^{V D}\right) .
$$

Further as it was compared, $p$ suppliers by Saaty's method due to the planned each criterion. Table 2 shows the matrix of weights for individual suppliers in terms of each criterion.

Table 2. Matrix of weights for each $p$ suppliers due to each $k$ criteria

\begin{tabular}{|c|c|c|c|c|c|}
\hline Supplier & $K_{1}^{V D}$ & $K_{2}^{V D}$ & $\cdots$ & $K_{k-1}^{V D}$ & $K_{k}^{V D}$ \\
\hline \multicolumn{6}{|l|}{$D_{1}$} \\
\hline \multicolumn{6}{|l|}{$D_{2}$} \\
\hline \multicolumn{6}{|l|}{$\ldots$} \\
\hline \multicolumn{6}{|l|}{$D_{p-1}$} \\
\hline$D_{p}$ & & & & & \\
\hline
\end{tabular}

Each elements $u_{i j}$ of matrix (Table 4) represent the weight of $i$ th supplier in relation to $j$ th criterion. Aggregated weight of each supplier can be calculated using the following formula:

$$
w D_{i}^{V D}=\sum_{j=1}^{k} w K_{j}^{V D} \cdot u_{i j}
$$

where: $w D_{i}^{V D}$ - aggregated weight of the $i$ th supplier, $i=$ $1,2, \ldots, p ; u_{i j}$ - weight of the $i$ th supplier in relation to jth criterion.
Aggregated weights of individual suppliers can be written in the form of aggregated weight vector:

$$
w D^{V D}=\left(w D_{1}^{V D}, w D_{2}^{V D}, \ldots, w D_{p}^{V D}\right) .
$$

From those calculations a suitable supplier can be chosen. Suitable supplier is one whose aggregated weight $w D_{i}^{V D}$ has the greatest value of the aggregated weight vector $w D^{V D}$ (Formula 15):

$$
M A X w D_{i}^{V D}=\max \left\{w D_{1}^{V D}, w D_{2}^{V D}, \ldots, w D_{p}^{V D}\right\} .
$$

The Formula (15) shows that, from the considered suppliers on the basis of selected criteria and the AHP method, the most suitable supplier is one which has the highest value of the aggregated weight vector $w D^{V D}$.

\section{Application of the Proposed Supplier Selection Model}

In this chapter, the application of the proposed model is made by example that deals with the selection of suppliers in one Czech manufacturing company.

The company needs a new supplier for a specific item. The company has three potential suppliers. They were asked to send theirs offer, which must include answers to the criteria for supplier selection. Based on this information, the criteria matrix can be filled (Table 3 ).

Weight of each criterion in each level was determined. This is shown in Table 4 in form of filled matrix (form of questionnaire) for one expert. Each expert had to fill this table according to his expertise. There were five experts in total.

To ensure maximum objectivity in determining the weights of the criteria for the selection of suitable supplier five experts were asked to determine the preferences of the individual criteria. The weights of the criteria were determined by using the Saaty's method.

According to Formulas (1) and (2) for the needs of this article, the soundness of experts can be written as weight vector:

$$
v=\left(v_{1}, v_{2}, \ldots, v_{r}\right)=(0,2 ; 0,2 ; 0,2 ; 0,2 ; 0,2 ;),
$$

where: $r=1,2, \ldots, 5$.

The weights of criteria were calculated by Saaty's method, using Formulas (5-9). Research was conducted on three suppliers and according to the mentioned criterion. Each criterion was made and filled in Table 2 and overall showed in Table 5.

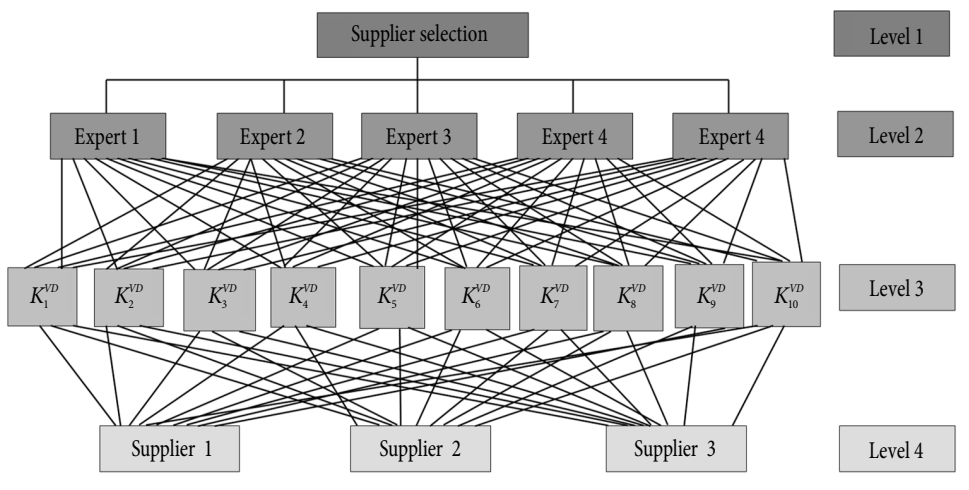

Fig. 2. Application of AHP method in this example - supplier selection 
Table 3. The criteria matrix for supplier selection

\begin{tabular}{|c|c|c|c|c|c|c|c|c|c|c|}
\hline & $K_{1}^{V D}$ & $K_{2}^{V D}$ & $K_{3}^{V D}$ & $K_{4}^{V D}$ & $K_{5}^{V D}$ & $K_{6}^{V D}$ & $K_{7}^{V D}$ & $K_{8}^{V D}$ & $K_{9}^{V D}$ & $K_{10}^{V D}$ \\
\hline$D_{1}$ & $\begin{array}{l}40 \mathrm{CZK} \\
\text { per unit; } \\
\text { choice of } \\
\text { currency } \\
\text { invoicing }\end{array}$ & $\begin{array}{l}\text { quality } \\
\text { certificate }\end{array}$ & $\begin{array}{l}\text { to } 30 \text { days; } \\
\text { quantity } \\
\text { discounts }\end{array}$ & $\begin{array}{l}14 \\
\text { days }\end{array}$ & $\begin{array}{l}\text { consignment } \\
\text { warehouse; } \\
\text { safety stocks } \\
\text { of the input } \\
\text { materials and } \\
\text { final products }\end{array}$ & $\begin{array}{l}\text { own space } \\
\text { and own } \\
\text { machines }\end{array}$ & $\begin{array}{l}\text { own } \\
\text { development; } \\
\text { the possible } \\
\text { development } \\
\text { of cooperation }\end{array}$ & $\begin{array}{l}\text { bar codes; } \\
\text { settlement } \\
\text { of claims to } \\
14 \text { days }\end{array}$ & $\begin{array}{l}\text { supplier } \\
\text { ensures } \\
\text { and pays }\end{array}$ & $\begin{array}{l}\text { complied } \\
\text { with audit } \\
\text { (minor } \\
\text { comments) }\end{array}$ \\
\hline$D_{2}$ & $\begin{array}{l}35 \mathrm{CZK} \\
\text { per unit }\end{array}$ & $\begin{array}{l}\text { quality } \\
\text { certificate }\end{array}$ & $\begin{array}{l}\text { to } 30 \text { days; } \\
\text { quantity } \\
\text { discounts }\end{array}$ & $\begin{array}{l}14 \\
\text { days }\end{array}$ & $\begin{array}{l}\text { no } \\
\text { consignment } \\
\text { warehouse; } \\
\text { safety stocks } \\
\text { of the input } \\
\text { materials and } \\
\text { final products }\end{array}$ & $\begin{array}{l}\text { own } \\
\text { space and } \\
\text { no own } \\
\text { machines } \\
\text { (leasing) }\end{array}$ & $\begin{array}{l}\text { own } \\
\text { development }\end{array}$ & $\begin{array}{l}\text { bar codes; } \\
\text { settlement } \\
\text { of claims to } \\
30 \text { days }\end{array}$ & $\begin{array}{l}\text { supplier } \\
\text { ensures } \\
\text { and } \\
\text { customer } \\
\text { pays }\end{array}$ & $\begin{array}{l}\text { complied } \\
\text { with audit } \\
\text { (no } \\
\text { comments) }\end{array}$ \\
\hline$D_{3}$ & $\begin{array}{l}45 \mathrm{CZK} \\
\text { per unit }\end{array}$ & $\begin{array}{l}\text { no quality } \\
\text { certificate }\end{array}$ & to 60 days & $\begin{array}{l}21 \\
\text { days }\end{array}$ & $\begin{array}{l}\text { no } \\
\text { consignment } \\
\text { warehouse; } \\
\text { no safety } \\
\text { stocks of } \\
\text { the input } \\
\text { materials and } \\
\text { final products }\end{array}$ & $\begin{array}{l}\text { no own } \\
\text { space and } \\
\text { no own } \\
\text { machines } \\
\text { (leasing) }\end{array}$ & $\begin{array}{l}\text { own } \\
\text { development; } \\
\text { possible } \\
\text { compatibility } \\
\text { of IS }\end{array}$ & $\begin{array}{l}\text { no bar } \\
\text { codes; } \\
\text { settlement } \\
\text { of claims to } \\
14 \text { days }\end{array}$ & $\begin{array}{l}\text { customer } \\
\text { ensures } \\
\text { and pays }\end{array}$ & $\begin{array}{l}\text { did not } \\
\text { comply } \\
\text { with audit }\end{array}$ \\
\hline
\end{tabular}

Table 4. Filled-in matrix of priority weights assigned to each criterion by one expert

\begin{tabular}{|c|c|c|c|c|c|c|c|c|c|c|}
\hline & $K_{1}$ & $K_{2}$ & $K_{3}$ & $K_{4}$ & $K_{5}$ & $K_{6}$ & $K_{7}$ & $K_{8}$ & $K_{9}$ & $K_{10}$ \\
\hline $\begin{array}{l}\text { Selection of } \\
\text { suppliers }\end{array}$ & Price & Quality & $\begin{array}{l}\text { Payment } \\
\text { terms }\end{array}$ & $\begin{array}{c}\text { Delivery } \\
\text { time }\end{array}$ & $\begin{array}{l}\text { Willingness } \\
\text { of hold stocks } \\
\text { by supplier }\end{array}$ & $\begin{array}{c}\text { Financial } \\
\text { situation } \\
\text { of } \\
\text { supplier }\end{array}$ & $\begin{array}{c}\text { Prospect } \\
\text { of supplier } \\
\text { development }\end{array}$ & Service & Transport & $\begin{array}{c}\text { Audit } \\
\text { of } \\
\text { supplier }\end{array}$ \\
\hline
\end{tabular}

\begin{tabular}{lllllllllll}
\hline$K_{1}$ & Price & 1 & 3 & 5 & 5 & 7 & 8 & 8 & 6 & 5 \\
\hline
\end{tabular}

\begin{tabular}{lllllllllll}
$K_{2}$ & Quality & $1 / 3$ & 1 & 5 & 5 & 7 & 8 & 8 & 6 & 5 \\
\hline
\end{tabular}

\begin{tabular}{|c|c|c|c|c|c|c|c|c|c|c|}
\hline$K_{3} \begin{array}{l}\text { Payment } \\
\text { terms }\end{array}$ & $1 / 5$ & $1 / 5$ & 1 & $1 / 3$ & 5 & 6 & 7 & 5 & 3 & 4 \\
\hline$K_{4} \begin{array}{l}\text { Delivery } \\
\text { time }\end{array}$ & $1 / 5$ & $1 / 5$ & 3 & 1 & 4 & 3 & 7 & 5 & 1 & 5 \\
\hline $\begin{array}{ll}\text { Willingness } \\
K_{5} & \begin{array}{l}\text { of hold } \\
\text { stocks by } \\
\text { supplier }\end{array}\end{array}$ & $1 / 7$ & $1 / 7$ & $1 / 5$ & $1 / 4$ & 1 & 4 & $1 / 5$ & $1 / 7$ & $1 / 3$ & 3 \\
\hline$K_{6} \begin{array}{l}\text { Financial } \\
\text { situation of } \\
\text { supplier }\end{array}$ & $1 / 8$ & $1 / 8$ & $1 / 6$ & $1 / 3$ & $1 / 4$ & 1 & 5 & $1 / 5$ & $1 / 3$ & 3 \\
\hline$K_{7} \begin{array}{l}\text { Prospect } \\
\text { of supplier } \\
\text { development }\end{array}$ & $1 / 8$ & $1 / 8$ & $1 / 7$ & $1 / 7$ & 5 & $1 / 5$ & 1 & $1 / 3$ & $1 / 3$ & 3 \\
\hline$K_{8}$ Service & $1 / 6$ & $1 / 6$ & $1 / 5$ & $1 / 5$ & 7 & 5 & 3 & 1 & 1 & 3 \\
\hline$K_{9}$ Transport & $1 / 5$ & $1 / 5$ & $1 / 3$ & 1 & 3 & 3 & 3 & 1 & 1 & 3 \\
\hline$K_{10} \begin{array}{l}\text { Audit of } \\
\text { supplier }\end{array}$ & $1 / 5$ & $1 / 5$ & $1 / 4$ & $1 / 5$ & $1 / 3$ & $1 / 3$ & $1 / 3$ & $1 / 3$ & $1 / 3$ & 1 \\
\hline
\end{tabular}


Table 5. Matrix of weights for three possible suppliers due

End of Table 5

\begin{tabular}{ccccccc}
\hline$K_{1}$ & $D_{1}$ & $D_{2}$ & $D_{3}$ & $s_{i}=\prod_{j=1}^{k} s_{i j}$ & $R_{i}=\sqrt[k]{s_{i}}$ & $v_{i}=\frac{R_{i}}{\sum_{j=1}^{k} R_{i}}$ \\
\hline$D_{1}$ & 1 & $1 / 3$ & 3 & 1.0000 & 1.0000 & 0.2583 \\
\hline$D_{2}$ & 3 & 1 & 5 & 15.0000 & 2.4662 & 0.6370 \\
\hline$D_{3}$ & $1 / 3$ & $1 / 5$ & 1 & 0.0667 & 0.4055 & 0.1047 \\
\hline & & & & $\sum_{j=1}^{k} R_{i}$ & 3.8717 & 1.0000 \\
& & & & & & $v_{i}=\frac{R_{i}}{k}$ \\
\hline$K_{2}$ & $D_{1}$ & $D_{2}$ & $D_{3}$ & $s_{i}=\prod_{j=1}^{k} s_{i j}$ & $R_{i}=\sqrt[k]{s_{i}}$ & $\sum_{j=1} R_{i}$ \\
\hline$D_{1}$ & 1 & 1 & 8 & 8.0000 & 2.0000 & 0.4706 \\
\hline$D_{2}$ & 1 & 1 & 8 & 8.0000 & 2.0000 & 0.4706 \\
\hline$D_{3}$ & $1 / 8$ & $1 / 8$ & 1 & 0.0156 & 0.2500 & 0.0588 \\
\hline & & & & $\sum_{j=1}^{k} R_{i}$ & 4.2500 & 1.0000 \\
& & & & & & \\
\hline & & & & & & \\
\hline
\end{tabular}

\begin{tabular}{|c|c|c|c|c|c|c|}
\hline$K_{6}$ & $D_{1}$ & $D_{2}$ & $D_{3}$ & $s_{i}=\prod_{j=1}^{k} s_{i j}$ & $R_{i}=\sqrt[k]{s_{i}}$ & $v_{i}=\frac{R_{i}}{\sum_{j=1}^{k} R_{i}}$ \\
\hline$D_{1}$ & 1 & 5 & 8 & 40.0000 & 3.4200 & 0.7188 \\
\hline $\mathrm{D}_{2}$ & $1 / 5$ & 1 & 6 & 1.2000 & 1.0627 & 0.2234 \\
\hline \multirow[t]{2}{*}{$D_{3}$} & $1 / 8$ & $1 / 6$ & 1 & 0.0208 & 0.2752 & 0.0578 \\
\hline & & & & $\sum_{j=1}^{k} R_{i}$ & 4.7578 & 1.0000 \\
\hline$K_{7}$ & $D_{1}$ & $D_{2}$ & $D_{3}$ & $s_{i}=\prod_{j=1} s_{i j}$ & $R_{i}=\sqrt[k]{s_{i}}$ & $v_{i}=\frac{R_{i}}{\sum_{j=1}^{k} R_{i}}$ \\
\hline$D_{1}$ & 1 & 7 & 5 & 35.0000 & 3.2711 & 0.7078 \\
\hline $\mathrm{D}_{2}$ & $1 / 7$ & 1 & $1 / 6$ & 0.0238 & 0.2877 & 0.0623 \\
\hline \multirow[t]{2}{*}{$D_{3}$} & $1 / 5$ & 6 & 1 & 1.2000 & 1.0627 & 0.2299 \\
\hline & & & & $\sum_{j=1}^{n} R_{i}$ & 4.6214 & 1.0000 \\
\hline$K_{8}$ & $D_{1}$ & $D_{2}$ & $D_{3}$ & $s_{i}=\prod_{j=1} s_{i j}$ & $R_{i}=\sqrt[k]{s_{i}}$ & $v_{i}=\frac{R_{i}}{\sum_{j=1}^{k} R_{i}}$ \\
\hline$D_{1}$ & 1 & 4 & 8 & 32.0000 & 3.1748 & 0.6840 \\
\hline $\mathrm{D}_{2}$ & $1 / 4$ & 1 & 7 & 1.7500 & 1.2051 & 0.2596 \\
\hline \multirow[t]{2}{*}{$D_{3}$} & $1 / 8$ & $1 / 7$ & 1 & 0.0179 & 0.2614 & 0.0563 \\
\hline & & & & $\sum_{j=1}^{k} R$ & 4.6413 & 1.0000 \\
\hline$K_{9}$ & $D_{1}$ & $D_{2}$ & $D_{3}$ & $s_{i}=\prod_{j=1} s_{i j}$ & $R_{i}=\sqrt[k]{s_{i}}$ & $v_{i}=\frac{R_{i}}{\sum_{j=1}^{k} R_{i}}$ \\
\hline$D_{1}$ & 1 & 6 & 7 & 42.0000 & 3.4760 & 0.7360 \\
\hline$D_{2}$ & $1 / 6$ & 1 & 5 & 0.8333 & 0.9410 & 0.1993 \\
\hline \multirow[t]{2}{*}{$D_{3}$} & $1 / 7$ & $1 / 5$ & 1 & 0.0286 & 0.3057 & 0.0647 \\
\hline & & & & $\sum_{j=1}^{k} R_{i}$ & 4.7228 & 1.0000 \\
\hline$K_{10}$ & $D_{1}$ & $D_{2}$ & $D_{3}$ & $s_{i}=\prod_{j=1}^{n} s_{i j}$ & $R_{i}=\sqrt[k]{s_{i}}$ & $v_{i}=\frac{R_{i}}{\sum_{j=1}^{k} R_{i}}$ \\
\hline$D_{1}$ & 1 & $1 / 3$ & 7 & 2.3333 & 1.3264 & 0.2966 \\
\hline $\mathrm{D}_{2}$ & 3 & 1 & 8 & 24.0000 & 2.8845 & 0.6450 \\
\hline \multirow[t]{2}{*}{$D_{3}$} & $1 / 7$ & $1 / 8$ & 1 & 0.0179 & 0.2614 & 0.0584 \\
\hline & & & & $\sum_{j=1}^{K} R_{i}$ & 4.4722 & 1.0000 \\
\hline
\end{tabular}

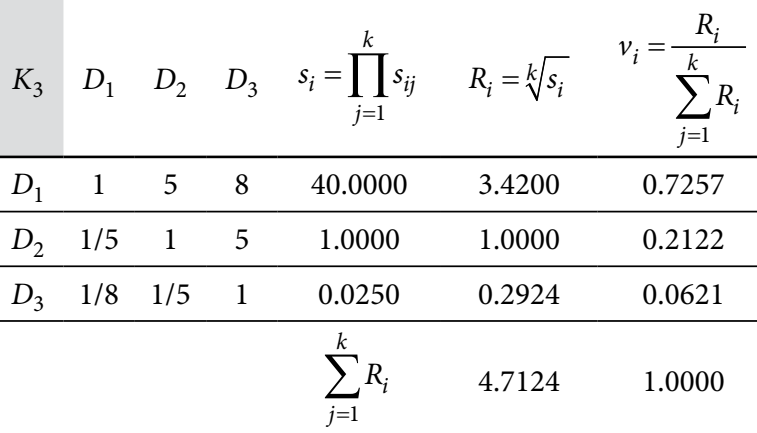

\begin{tabular}{ccccccc}
$K_{4}$ & $D_{1}$ & $D_{2}$ & $D_{3}$ & $s_{i}=\prod_{j=1}^{k} s_{i j}$ & $R_{i}=\sqrt[k]{s_{i}}$ & $v_{i}=\frac{R_{i}}{\sum_{j=1}^{k} R_{i}}$ \\
\hline$D_{1}$ & 1 & 1 & 5 & 5.0000 & 1.7100 & 0.4545 \\
\hline$D_{2}$ & 1 & 1 & 5 & 5.0000 & 1.7100 & 0.4545 \\
\hline$D_{3}$ & $1 / 5$ & $1 / 5$ & 1 & 0.0400 & 0.3420 & 0.0909 \\
\hline & & & & & \\
& & & & & \\
& & & & &
\end{tabular}

\begin{tabular}{ccccccc}
\hline$K_{5}$ & $D_{1}$ & $D_{2}$ & $D_{3}$ & $s_{i}=\prod_{j=1}^{k} s_{i j}$ & $R_{i}=\sqrt[k]{s_{i}}$ & $v_{i}=\frac{R_{i}}{\sum_{j=1}^{k} R_{i}}$ \\
\hline$D_{1}$ & 1 & 5 & 9 & 45.0000 & 3.5569 & 0.7429 \\
\hline$D_{2}$ & $1 / 5$ & 1 & 4 & 0.8000 & 0.9283 & 0.1939 \\
\hline$D_{3}$ & $1 / 9$ & $1 / 4$ & 1 & 0.0278 & 0.3029 & 0.0633 \\
\hline & & $\sum_{j=1}^{k} R_{i}$ & 4.7881 & 1.0000
\end{tabular}


Based on these results Table 6 shows the matrix of criteria weights assigned by all experts (Hruška 2011).

Table 6. Matrix of criteria weights assigned by experts

\begin{tabular}{llllll}
\hline Expert & Expert $_{1}$ & Expert $_{2}$ & Expert $_{3}$ & Expert $_{4}$ & Expert $_{5}$ \\
\hline$K_{1}^{V D}$ & 0.3059 & 0.2124 & 0.1724 & 0.1304 & 0.1745 \\
\hline$K_{2}^{V D}$ & 0.2456 & 0.3232 & 0.1815 & 0.2273 & 0.2828 \\
\hline$K_{3}^{V D}$ & 0.1091 & 0.1120 & 0.1100 & 0.1160 & 0.0924 \\
\hline$K_{4}^{V D}$ & 0.1136 & 0.0641 & 0.1738 & 0.1758 & 0.0495 \\
\hline$K_{5}^{V D}$ & 0.0264 & 0.1042 & 0.0777 & 0.0763 & 0.0907 \\
\hline$K_{6}^{V D}$ & 0.0281 & 0.0364 & 0.0487 & 0.0843 & 0.0329 \\
\hline$K_{7}^{V D}$ & 0.0262 & 0.0128 & 0.0288 & 0.0813 & 0.0124 \\
\hline$K_{8}^{V D}$ & 0.0589 & 0.0394 & 0.1238 & 0.0463 & 0.0353 \\
\hline$K_{9}^{V D}$ & 0.0659 & 0.0737 & 0.0498 & 0.0285 & 0.0550 \\
\hline$K_{10}^{V D}$ & 0.0203 & 0.0218 & 0.0335 & 0.0338 & 0.1745 \\
\hline
\end{tabular}

The aggregated weight for each criterion was calculated according to Formula (11), and according to Formula (12) the aggregated weights of criteria, can be written in the aggregated weight vector:

$$
\begin{aligned}
& w K^{V D}=(0.1991 ; 0.2521 ; 0.1079 ; 0.1154 ; 0.0751 ; \\
& 0.0461 ; 0.0323 ; 0.0607 ; 0.0546 ; 0.0568) \text {. }
\end{aligned}
$$

Further as it was compared, $p$ suppliers by Saaty's method due to the planned each criterion (Table 7).

The aggregated weight for each supplier was calculated according to Formula (13), and according to Formula (14) the aggregated weights of suppliers can be written in the aggregated weight vector:

$$
w D^{V D}=(0.5111 ; 0.4109 ; 0.0780) \text {. }
$$

The suitable supplier for the company is chosen on the basis of the Formula (13):

$$
\begin{aligned}
& M A X w D_{i}^{V D}=\max \left\{w D_{1}^{V D}, w D_{2}^{V D}, w D_{3}^{V D}\right\} ; \\
& M A X w D_{i}^{V D}=\max \{0.5111 ; 0.4109 ; 0.0780\} ; \\
& M A X w D_{1}^{V D}=0.5111 .
\end{aligned}
$$

Based on the Formula (15), which shows overall scores for proposed suppliers on the basis of selected criteria and the AHP method, supplier $D_{1}$ should be selected as the best supplier overall because it obtained the highest ranking with a score of 0.5111 . From the above calculations we can see that supplier D2 quality service score is 0.4109 whereas supplier $D_{3}$ has quality service score of 0.0780 .
Even that supplier $D_{1}$ has much lower weight on criterion $K_{1}$ - price $(0.2583)$ then supplier $D_{2}(0.6370)$ and criterion $K_{1}$ has the highest weight among all other criterions, supplier $D_{1}$ was chosen because it has higher score on almost all other criterions comparing to supplier $D_{2}$. If we compare overall results of supplier $D_{1}$ to supplier $D_{3}$, we can see that supplier $D_{1}$ has much higher score in every criterion except $K_{10}$ (audit of supplier).

\section{Conclusions}

Many researchers and practitioners have focused their work on supplier selection in supply chain management area and deployed a wide range of scientific and technical techniques to enhance efficiency and flexibility of the supply networks and various approaches are available for supplier selection.

Each production company, which is a part of the supply chain, has its contractors. Decisions about the appropriate suppliers are a major problem, since it is assumed that this will be the cooperation extended period of time. When choosing a new supplier, company must take into account all relevant factors (criteria) that have a significant influence on this decision. In this paper the method of Analytical Hierarchical Process (AHP), was used, as one of the possible methods for supplier selection.

The main contribution of this paper is a multi-criteria decision model for evaluating and selecting a supplier. The model for supplier evaluation and selection was developed using the AHP method, like mentioned above and with identification and evaluation of the important criteria for the supplier selection process.

Finally, the developed model is tested on one supplier selection problem. The results show that the model is able to assist decision-makers to examine the strengths and weaknesses of supplier selection by comparing them with appropriate defined criteria.

The proposed model can be applied easily in practical situations. Expertise, experience, authority and the responsibilities of decision makers are not equal in practice. Furthermore, in the presented model, the weights of criteria are determined by decision makers. It is useful to propose a scientific method for determining these weights.

\section{Acknowledgement}

The Ministry of Education, Youth and Sports of the Czech Republic, Project POSTDOK, CZ.1.07/2.3.00/30.0021 'Enhancement of R\&D Pools of Excellence at the University of Pardubice', which financially supported this work.

Table 7. Matrix of weight of each $p$ suppliers due to each $K$ criteria

\begin{tabular}{lllllllllll}
\hline Supplier & $K_{1}^{V D}$ & $K_{2}^{V D}$ & $K_{3}^{V D}$ & $K_{4}^{V D}$ & $K_{5}^{V D}$ & $K_{6}^{V D}$ & $K_{7}^{V D}$ & $K_{8}^{V D}$ & $K_{9}^{V D}$ & $K_{10}^{V D}$ \\
\hline$D_{1}$ & 0.2583 & 0.4706 & 0.7257 & 0.4545 & 0.7429 & 0.7188 & 0.7078 & 0.6840 & 0.7360 & 0.2966 \\
\hline$D_{2}$ & 0.6370 & 0.4706 & 0.2122 & 0.4545 & 0.1939 & 0.2234 & 0.0623 & 0.2596 & 0.1993 & 0.6450 \\
\hline$D_{3}$ & 0.1047 & 0.0588 & 0.0621 & 0.0909 & 0.0633 & 0.0578 & 0.2299 & 0.0563 & 0.0647 & 0.0584 \\
\hline
\end{tabular}




\section{References}

Barbarosoglu, G.; Yazgac, T. 1997. An application of the analytic hierarchy process to the supplier selection problem, Production and Inventory Management Journal 38(1): 14-21.

Bitarafan, M.; Hashemkhani Zolfani, S.; Arefi, S. L.; Zavadskas, E. K. 2012. Evaluating the construction methods of cold-formed steel structures in reconstructing the areas damaged in natural crises, using the methods AHP and COPRAS-G, Archives of Civil and Mechanical Engineering 12(3): 360-367. http://dx.doi.org/10.1016/j.acme.2012.06.015

Cavinato, L. J.; Flynn, A. E.; Kauffman, R. G. 2006. The Supply Management Handbook. 7th edition. McGraw-Hill. 1000 p.

Ghodsypour, S. H.; O’Brien, C. 1997. An integrated method using the analytical hierarchy process with goal programming for multiple sourcing with discounted prices, in Proceedings of the 14th International Conference on Production Research (ICPR), 4-8 August, 1997, Osaka, Japan, 13-17.

Ghodsypour, S. H.; O’Brien, C. 2001. The total cost of logistics in supplier selection, under conditions of multiple sourcing, multiple criteria and capacity constraint, International Journal of Production Economics 73(1): 15-27. http://dx.doi.org/10.1016/S0925-5273(01)00093-7

Hashemkhani Zolfani, S.; Chen, I.-S.; Rezaeiniya, N.; Tamošaitienè, J. 2012. A hybrid MCDM model encompassing AHP and COPRAS-G methods for selecting company supplier in Iran, Technological and Economic Development of Economy 18(3): 529-543. http://dx.doi.org/10.3846/20294913.2012.709472

Hill, R. P.; Nydick, R. L. 1992. Using the analytic hierarchy process to structure the supplier selection procedure, International Journal of Purchasing and Materials Management 28(2): 31-36.

Hruška, R. 2011. Interakce nových informačních technologií a logistiky. Disertační práce. Univerzita Pardubice, Česká republika. 119 s. Available from Internet: http://dspace.upce. cz/handle/10195/42223 (in Czech).

Hsu, C.-C.; Kannan, V. R.; Leong, G. K.; Tan, K.-C. 2006. Supplier selection construct: instrument development and validation, International Journal of Logistics Management 17(2): 213-239. http://dx.doi.org/10.1108/09574090610689961

Huang, S. H.; Keskar, H. 2007. Comprehensive and configurable metrics for supplier selection, International Journal of Production Economics 105(2): 510-523. http://dx.doi.org/10.1016/j.ijpe.2006.04.020

Kagnicioglu, C. H. 2006. A fuzzy multiobjective programming approach for supplier selection in a supply chain, The Business Review, Cambridge 6(1): 107-115.

Kampf, R.; Roudná, J. 2009. The benchmarking in logistic centres environment, Scientific Papers of the University of Pardubice, Series B 2008(14): 215-224.

Kannan, V. R.; Tan, K. C. 2002. Supplier selection and assessment: their impact on business performance, Journal of Supply Chain Management 38(3): 11-21. http://dx.doi.org/10.1111/j.1745-493X.2002.tb00139.x

Kumar, M.; Vrat, P.; Shankar, R. 2004. A fuzzy goal programming approach for vendor selection problem in a supply chain, Computers \& Industrial Engineering 46(1): 69-85. http://dx.doi.org/10.1016/j.cie.2003.09.010

Lasch, R.; Janker, C. G. 2005. Supplier selection and controlling using multivariate analysis, International Journal of Physical Distribution \& Logistics Management 35(6): 409-425. http://dx.doi.org/10.1108/09600030510611648
Lin, R.-H. 2009. Potential use of FP-growth algorithm for identifying competitive suppliers in SCM, Journal of the Operational Research Society 60(8): 1135-1141.

http://dx.doi.org/10.1057/jors.2008.157

Lukoszová, X. 2004. Nákup a jeho řízení. Computer Press. 182 s. (in Czech).

Maron, B.; Brückner, J. 1998. Aktives Lieferantenmanagement, Qualität und Zuverlässigkeit 43(6): 718-722 (in German).

Maskeliūnaite, L.; Sivilevičius, H. 2012. Expert evaluation of criteria describing the quality of travelling by international passenger train: technological, economic and safety perspectives, Technological and Economic Development of Economy 18(3): 544-566.

http://dx.doi.org/10.3846/20294913.2012.710178

Morlacchi, P. 1999. SMEs in supply chain: a supplier evaluation model and some empirical results, in Research Perspectives in Purchasing and Supply Chain Management: Selected Papers of the Third and Fourth IFPMM Summer Schools. IFPMM Summer School Secretariat, Salzburg, 77-92.

Podvezko, V.; Mitkus, S.; Trinkūnienė, E. 2010. Complex evaluation of contracts for construction, Journal of Civil Engineering and Management 16(2): 287-297. http://dx.doi.org/10.3846/jcem.2010.33

Pooler, V. H.; Pooler, D. J.; Farney, S. D. 2004. Global Purchasing and Supply Management: Fulfill the Vision. 2nd edition. Springer. $443 \mathrm{p}$.

Saaty, T. L. 1980. The Analytic Hierarchy Process. McGraw-Hill. $287 \mathrm{p}$.

Timmermann, E. 1987. An approach to vendor performance evaluation, IEEE Engineering Management Review 15(3): 14-20. http://dx.doi.org/10.1109/EMR.1987.4306294

Tomek, J.; Hofman, J. 1999. Moderní rízení nákupu podniku. Management Press. 276 s. (in Czezh).

Verma, R., Pullman, M. E. 1998. An analysis of the supplier selection process, Omega 26(6): 739-750. http://dx.doi.org/10.1016/S0305-0483(98)00023-1

Wang, W.-C.; Yu, W.-D.; Yang, I.-T.; Lin, C.-C.; Lee, M.-T.; Cheng, Y.-Y. 2013. Applying the AHP to support the bestvalue contractor selection - lessons learned from two case studies in Taiwan, Journal of Civil Engineering and Management 19(1): 24-36. http://dx.doi.org/10.3846/13923730.2012.734851

Van Weele, A. J. 2010. Purchasing and Supply Chain Management: Analysis, Strategy, Planning and Practice. 5th edition. Cengage Learning EMEA. 448 p.

Weber, C. A.; Current, J. R.; Benton, W. C. 1991. Vendor selection criteria and methods, European Journal of Operational Research 50(1): 2-18. http://dx.doi.org/10.1016/0377-2217(91)90033-R

Zhang, Z.; Lei, J.; Cao, N.; To, K.; Ng, K. 2004. Evolution of Supplier Selection Criteria and Methods. The Hong Kong Polytechnic University, Hong Kong. 